\title{
Extended teams in vocational education: Collaboration on the border
}

Citation for published version (APA):

Mazereeuw, M., Wopereis, I., \& McKenney, S. (2016). Extended teams in vocational education: Collaboration on the border. Educational Research and Evaluation, 22(3-4), 194-212.

https://doi.org/10.1080/13803611.2016.1247727

DOI:

10.1080/13803611.2016.1247727

Document status and date:

Published: 24/10/2016

Document Version:

Early version, also known as pre-print

Document license:

CC BY-NC-ND

Please check the document version of this publication:

- A submitted manuscript is the version of the article upon submission and before peer-review. There can be important differences between the submitted version and the official published version of record. People interested in the research are advised to contact the author for the final version of the publication, or visit the DOI to the publisher's website.

- The final author version and the galley proof are versions of the publication after peer review.

- The final published version features the final layout of the paper including the volume, issue and page numbers.

Link to publication

\section{General rights}

Copyright and moral rights for the publications made accessible in the public portal are retained by the authors and/or other copyright owners and it is a condition of accessing publications that users recognise and abide by the legal requirements associated with these rights.

- Users may download and print one copy of any publication from the public portal for the purpose of private study or research.

- You may not further distribute the material or use it for any profit-making activity or commercial gain

- You may freely distribute the URL identifying the publication in the public portal.

If the publication is distributed under the terms of Article 25fa of the Dutch Copyright Act, indicated by the "Taverne" license above, please follow below link for the End User Agreement:

https://www.ou.nl/taverne-agreement

Take down policy

If you believe that this document breaches copyright please contact us at:

pure-support@ou.nl

providing details and we will investigate your claim.

Downloaded from https://research.ou.nl/ on date: 26 Apr. 2023 


\title{
Extended teams in vocational education: Collaboration on the border
}

\author{
Marco Mazereeuw ${ }^{*}$ \\ NHL University of Applied Sciences \\ PO Box 1080 \\ 8900 CB Leeuwarden, \\ The Netherlands \\ m.mazereeuw@nhl.nl
}

Marco Mazereeuw is associate professor and teacher trainer at NHL University of Applied Sciences. His research focuses on learning processes in vocational education with a special interest in workplace learning.

Iwan Wopereis

Open University of the Netherlands

PO Box 2960

6401 DL Heerlen

The Netherlands

iwan.wopereis@ou.nl

Iwan Wopereis is lecturer and $\mathrm{PhD}$ candidate in educational sciences at the Open University of the Netherlands. His research interests are in instructional design, information literacy, and creativity.

\author{
Susan McKenney \\ University of Twente \\ PO Box 217 \\ 7500AE Enschede \\ The Netherlands \\ susan.mckenney@utwente.nl
}

Susan McKenney is professor of teacher professionalization, school development and educational technology at the University of Twente in the Netherlands. Her research focuses on these three themes, especially in relation to curriculum design. She also studies synergetic research-practice interactions.

This work was supported by 'Het Platform Beroepsonderwijs' The Platform for Vocational Education and Training in The Netherlands [Grant number: A11217].

This is a preprint of:

Mazereeuw, M., Wopereis, I., \& McKenney, S. (2016). Extended teams in vocational education:

Collaboration on the border. Educational Research and Evaluation, 22, 194-212.

doi:10.1080/13803611.2016.1247727

\footnotetext{
*Corresponding author.m.mazereeuw@nhl.nl
} 


\title{
Extended teams in vocational education: Collaboration on the border
}

\begin{abstract}
Extended Teams (ETs), in which teachers and workplace supervisors are jointly responsible for the quality of education, were established to solve problems concerning school-workplace connections in vocational and professional education. Six ETs were investigated during their first year of collaboration. In addition to recordings of ET meetings, questionnaires, focus groups and interviews yielded triangulation of data pertaining to dimensions of team work and professional growth of individual team members. Five of the six teams showed marked changes for team functioning, especially with regard to social ties and intellectual building as well as needs for new knowledge. Analysis of individual professional growth indicated that working in an ET contributed to understanding the other context, and altering views of what can be achieved by and for students. We conclude that ETs hold potential for strengthening school-workplace connections, but note that they did rely heavily on external support.
\end{abstract}

Key words: team development; extended team; professional development; vocational education; apprenticeship.

\section{Introduction}

The connection between student learning in the workplace and in the vocational training context is a source of discontent for both teachers and workplace supervisors (e.g., Schaap, Baartman, \& De Bruijn, 2012; Truijen, Sleegers, Meelissen, \& Nieuwenhuis, 2013; Tynjälä, 2008). Extended Teams (ETs), in which teachers and workplace supervisors are jointly responsible for the quality of education, are viewed as a potential solution to the connection problem (Nieuwenhuis, Nijman, Kat-De Jong, De Ries, \& Van Vijfeijken, 2011). ETs operate on the border between education and the workplace, and its members can therefore be seen as 'boundary crossers' who can connect both contexts with one another (see also Akkerman \& Bakker, 2011). We investigated ETs within the senior secondary and tertiary level vocational education, and focus on the performance of whole teams as well as individuals within them. With the ultimate goal of shaping appropriate support for various development phases, we examined changes in ETs over one year as they worked on specific tasks.

The ETs involved in this study can be described as working groups, because they constitute a collection of persons in a professional context carrying out a professional task. According to Tuckman (1965), working groups progress through the phases of forming, storming, norming and performing. In the first phase, forming, participants are primarily concerned with their identity within a group and the organizational aspects of the teamwork. Targets are formed, and tasks are often divided. Difficult issues are pushed aside, and participants do their best to adopt constructive and social attitudes. Normally this is a relatively comfortable stage. Yet, it is important that this phase is successful because it appears to form the basis for the rest of the process. During the second phase, storming, various ideas are introduced and compete with each other for attention. During this phase, team members begin to talk about substantive issues and the personal beliefs of participants come more explicitly into the limelight. It can be a very difficult, uncomfortable phase. This depends primarily on the personal maturity of the participants and expertise that exists in the group. Then, during the norming phase, the team focuses on how the common goals can be achieved. In this phase the targets that were formed in the first phase are refined and team members create a shared view on how they should be 
achieved. Because research on teacher professional development shows that the personal vision of teachers is strongly influenced by their own practical experiences, it can be assumed that during this phase there will be an interaction between thinking about the design and experimentation in practice. At the fourth stage, performing, teams function competently and autonomously and have little need for external input. While the ETs participating in the present study progressed through the four phases mentioned above, this paper reports on the first year of ET collaboration. The analyses describe various dimensions of team work and professional development of individuals during the year investigated, in which the ETs completed the first two phases of the Tuckman model (forming and storming).

\section{Theoretical background}

\section{Dimensions of team work}

Communities of practice (CoPs) are groups of people with shared interests, who learn that working on these shared interests can be improved through regular interaction with each other (Wenger, 1998). Although, Wenger's definition of a CoP does not directly concern teams, we note that well-performing teams also show characteristics of a CoP (Brouwer, Brekelmans, Nieuwenhuis, \& Simons, 2012). Accordingly, in our view, ETs featuring program-based educators and workplace supervisors that work collaboratively and sustainably to align learning, are CoPs. Their efforts 'extend' prevailing organizational structures in vocational education and practice. Members of ETs have strong ties to school and/or practice which are drawn upon and used by the various members. Thus, in the landscape of workplace learning, ETs represent a specific type of CoP.

According to Wenger (1998), working in CoPs demands mutual engagement through $a$ shared repertoire and joint enterprise. Through mutual engagement, relationships and interactions within the social unit arise. Based on Admiraal and Lockhorst (2010), Brouwer et al. (2012) describe four indicators for mutual engagement: (a) identification (how members identify themselves with the group); (b) multi-perspective contribution (space for different ideas in the group); (c) mutual trust and responsibility (feeling responsible for the team and other members); and (d) social ties (between group members). As time passes, a CoP develops a common repertoire of routines, tools, conventions, and concepts. Brouwer et al. (2012) suggest four indicators for the creation of a shared repertoire: (a) intellectual building (building on each other's contributions); (b) regulation of interaction (through organization, discussion and reflection); (c) role-taking (accepting and taking roles, tasks, and positions within the group); and (d) dynamic effort (flexibility in dealing with differences of commitment, activity, and task performance within the group). Finally, joint enterprise is a set of shared beliefs about the group and its function. Brouwer et al. (2012) identify four indicators for joint enterprise: (a) commitment to domain (group members agree on the subject and the goals being worked on); (b) common ground in concept (group members interpret concepts in similar fashion, but are also aware of differences); (c) collective goal (group members build on each other to achieve goals); and (d) shared knowledge (group members share knowledge and support each other in its use). The assistance that was offered to the ETs in this project encourages the development of mutual engagement, shared repertoire and joint enterprise. 


\section{Professional development of team members}

The functioning of a team is naturally influenced by the individual team members. But the members do not remain static. Rather, participation in CoPs often leads to professional development of its members (Lieberman \& Pointer Mace, 2010; McLaughlin \& Talbert, 2006), and these developments could in turn affect new group processes. The Interconnected Model of Professional Growth (IMPG, see Figure 1) by Clarke and Hollingsworth (2002) describes the dynamic process of personal development in interaction with the educational environment.

[Insert Figure 1 about here]

The IMPG model includes four domains in which and through which development takes place. Three areas have a direct relationship with the educational professional: the personal domain (knowledge, skills, and attitudes of the individual); the domain of practice (which includes experimentation, such as designing / developing interventions); and the domain of consequence (outcomes of new initiatives). The fourth domain is external and includes sources of information or stimulus and support to undertake new actions. Through reflection or enactment, change in one domain leads to change in another domain (Clarke \& Hollingsworth, 2002). This model helps to conceptualize and study the functioning of individuals in relation to the CoPs.

Based of the work of Tuckman (1965), it can be predicted that ETs will pass through various development stages. With this given, it is therefore very likely that the different dimensions of team functioning (see Brouwer et al., 2012; Wenger, 1998) will manifest themselves in various ways over time. Because these group level dimensions mainly consist of interactions between individuals, it is not only the developments of teams, but also the individual development of domains of professional growth (cf. Clarke \& Hollingsworth, 2002) that determine the final results of team work. Systematic descriptions of the development of ETs and individuals within them are hardly available in the current literature. Yet such descriptions can be essential for anticipating the support needed by these teams during various stages of collaboration.

\section{The aim of the study}

The ET is a new organizational form in vocational education (Nieuwenhuis et al., 2011). This study examines the performance of these partnerships, taking into account developments as the levels of both teams and individuals. Because ETs seem very promising to help close the gap between school and workplace learning, further insights relating to ETs and their functioning are needed. To facilitate in-depth investigation and reporting, the project was divided in three parts of one school year. A school year is a substantial unit of analysis as it is in accordance with the developmental cycle of educational institutions and various stages of reflection. This study focuses on the first year of ET activities. The main question in this study is therefore: How do ETs and their members function during the first year of cooperation?

The sub-questions are as follows:

(1) In which dimensions of team functioning do ETs exhibit changes during the first year?

(2) In which domains of professional growth do team members exhibit individual professional growth during the first year? 


\section{Methods}

\section{Team composition}

Team formation was informed by literature, which indicates that team performance is positively associated with task-related diversity, but not or sometimes even negatively associated with demographic diversity (Horwitz \& Horwitz, 2007; Joshi \& Roh, 2009). As a consequence, we strived for diversity in the teams that reflected the task-diversity in the domains. It is for this reason that team formation was stipulated in consultation with school leaders and directors of the schools and workplaces involved. What is more, the size of the teams intentionally reflected what participating institutions deemed practical. Finally, to qualify as an ET, at least one teacher and one workplace supervisor were required, for a minimum of two participants. Following these guidelines, the team size varied between two and five members per team.

To answer the research questions, the six ETs were viewed as case studies (see Yin, 2003). The six ETs related to the domains of education (Edu), economics (Eco), and technology (Tech). Two types of teams were formed for each domain: one from higher vocational education (HVE) and one from senior secondary vocational education (SVE). An overview of teams and their characteristics is given in Table 1. The Edu-HVE ET consisted out of four team members. Two team members worked as a teacher at a teacher-training institute and two team members were employed as a teacher at a comprehensive school for secondary education. The Edu-SVE ET consisted out of five team members. Two members work as a teacher at a senior secondary vocational education institute that educates teacher assistants and three members were employed as an elementary school teacher. The Tech-HVE ET consisted of three team members, two members were employed as a teacher at a polytechnic and a team member works at a large consumer lifestyle electronic equipment company. The Tech-SVE ET consists of three members of which two are teachers at a school for secondary vocational education and one is working in a mechanical engineering company. The Eco-HVE ET consists of three team members, one of which works as a teacher at a higher professional education institute and two are working as business administrator in different companies. The Eco-SVE ET has two team members. One team member is employed as a teacher at a senior secondary vocational education institute and the other member works as an independent accountant.

[Insert Table 1 about here]

\section{Procedures}

Before the ETs were formally introduced to each other, all participants individually filled out a questionnaire about their current habits and beliefs with regard to workplace learning, as well as expectations of the project. Then during a period of six months the ETs got together to shape educational interventions in the workplace learning of students. Because the participating institutions deemed meetings about every six weeks as practical, four meetings were held during this six month period. These meetings were led by trainers / researchers of the project. The ET conversations were recorded during all four meetings. In hindsight, we relate the meetings to the aforementioned phases. The first and second meetings can be conceived as part of the forming phase; since the teams were focused on getting acquainted, setting common goals, and reflecting on possible ways to achieve these goals. Then, during the third and fourth meeting the storming phase began. In these meetings specific interventions were designed. Additional meetings were offered. However, during the four meetings the teams indicated that they had no need for that. 
The meetings were followed by three months of self-organized consultation sessions to help shape interventions. The support of the trainers / researchers was available on demand. The members of ETs were stimulated to communicate through various media (see also Kirschner \& Wopereis, 2003), including electronic tools that were offered in the four meetings (i.e., Google Drive $^{(}$and Skype ${ }^{\circledR}$ ). Access to the shared workspace environment gave the research team insight into team progress and frequency of interaction. After five months of working in the ET each participant was interviewed once. After that, a focus group discussion with each team was held and recorded. These interviews also examined how the period of self-organization proceeded. At the end of the school year all the participants filled out the same questionnaire once more.

\section{Instrumentation}

There are four sources of data in this study: two mainly helped understand team functioning and two mainly helped gain insight into individual professional growth. Audio recordings of team conversations during the supervised meetings as well as of focus group discussions with the teams afforded the opportunity to examine team interactions objectively and unobtrusively. Because self-reporting was deemed appropriate for investigating (and prompting reflection on) individual professional growth, these data were collected through a questionnaire and interviews with individual team members. To a limited extent, interviewees commented on group functioning and group discussions also revealed information about individuals. These instances were used to help check and target the qualitative data analysis. They did not change the coding schemes used. The data sources are described next, following the same sequence in which the data were collected.

The questionnaire was filled out at the start and at the end of the first year, and included both open and closed questions. The questionnaire was based on the IMPG model (Clarke \& Hollingsworth, 2002), raising questions about each domain shown in Figure 1. An example of an open question about the personal domain, more specifically about the relationship between learning at school and at work is: "What do you think are three powerful ways to connect school and workplace learning?" An example of a closed question that refers to the domain of practice (specifically about the organization) is: "Are you satisfied with the ways connections of learning at school and workplace learning are now shaped in your organization?" This question had "very satisfied", "satisfied", " neither satisfied nor dissatisfied "," dissatisfied", and " very dissatisfied "

as possible choices. The results of the closed questions were summarized and compared. The results of the open questions were inductively coded and compared (Miles \& Huberman, 1994).

The team talks were recorded during the four meetings. The audio recordings were used for conversation analysis. Video-recordings were used to capture the entire meeting, and, when necessary to identify who was speaking at a given time. These video recordings were not used for further analysis. The duration of talks varied per task and per meeting. In the meetings $(n=4)$, the total time the teams were working on the tasks was about 180 minutes. The meetings and the tasks were planned by the project supervisors. For example, one task featured a discussion of the strengths, weaknesses, opportunities and threats of changes within the contexts related to their own team. In total there were on average two tasks per meeting (for a total of eight separate conversations). Within each conversation, semantic units (units of meaning) were identified. According to Aviv (2001, p. 59) a unit of meaning is "a statement or a continuous set of statements-which convey one Identifiable idea." Each conversation was first transcribed and then chunked into semantic units. Then each unit was analyzed for the three dimensions by Wenger (1998) and the indicators of Brouwer et al. (2012). 
After about eight months of participation in the ET, telephone interviews were conducted with a semi-structured protocol. The protocol was based on the dimensions of Wenger and the domains of the IMPG-model. During the interview, key questions from the questionnaire were discussed again, which made elaboration and refinement of previously formulated answers possible. A sample question based on the IMPG model (personal domain) is: "What are the most important components of workplace learning?" A sample question about group functioning (shared repertoire) was: "What role do you have in the team?" The interviews were recorded (only audio) and transcripts were used for further analysis. The answers to the questions based on the IMPG model were used to answer the research question about professional growth. The answers to the questions that were based on the dimensions of Wenger gave insight into the functioning within the ET.

During the focus group discussions summaries of the interview findings were presented to the participants. Next, discussions were held with the aid of a protocol. Because the focus group discussion was mainly intended to discuss team performance, this protocol was structured on the basis of the dimensions of Wenger (1998). In addition, the audio recordings of the focus group discussions were transcribed. The transcriptions were analyzed on the basis of the dimensions of Wenger (1998) and the indicators of Brouwer et al. (2012).

\section{Analyses}

The analysis to reveal domains of professional growth for team members (Clarke \& Hollingsworth, 2002) included (1) assigning codes for each domain (personal, experimentation, consequence, external) and relationships based on the answers given by team members; (2) clustering answers per team member and domain; (3) searching for similarities and changes within domains; and (4) a final comparison and summary of marked changes put forward by team members. Similarly, the analysis to reveal the dimensions of team functioning (Brouwer et al. 2012; Wenger 1998) consisted of (1) assigning codes for each dimension (mutual engagement, shared repertoire and joint enterprise) and the above-described indicators for each dimension to each unit of meaning; (2) clustering units per team, dimension and indicator; (3) identification and assessment of indicators ('neutral', 'positive', or 'negative') for each ET.

\section{Results}

The results are presented in two parts. The first part describes the results of the analyses of the interviews of the team members during the counseling sessions, interviews and focus group discussions. This mainly describes changes in the teams during the forming phase and the storming phase. The second part describes the results of the analyses of the comparison of the questionnaires prior to and after the first year, and the comparison of the individual interviews. This section therefore describes professional growth of the individuals during the forming phase and the storming phase.

\section{Team Development: Mutual engagement}

The first discussions of the teams during the first workshop make clear that in this stage the team members particularly scan who the members of the group are, what their (opposing) views on workplace learning are and what the main goals and problems of workplace learning are. For some teams, members already have a working relationship. For example, two members had been supervising the same student. However, it is the first time they came together to design, implement and evaluate workplace learning. In the ETs members seem to be interested in the ideas of the other members from the very start. 
In the second meeting, members in all teams seem to allow different perspectives from each other, in relation to the school and workplace. However, these different perspectives are not always endorsed by the other team members. As a result, a disagreement about the feasibility of targets in their own context was manifest in the Eco-HVE ET. The talk of the members of the Tech-HVE ET below also shows that different ideas of, in this case, an internship are being discussed. This ET searched for a better match between student and business before doing work placement.

(W: workplace supervisor technology; P: program supervisor Construction Technology)

$\mathrm{W}$ : If a student does work placement in our company under my supervision, things go as I plan. That is the current practice.

$[\ldots]$

P: You've been supervising students for 25 years now?

W: Indeed, I'm not quite sure but something like that. In total about 100 students.

P: You must have a clear vision of what you want to teach students and how an internship should progress?

W: No, that's not true. I have a technical ambition and students can help me to realize that ambition. As long as this is not in conflict with student learning it is permitted. That's how it works now. That is the engine.

P: Apparently you do have an idea that there is a learning process. You do know that he is going to learn something in the internship? You probably do not have the idea that the student does the internship and fulfills his assignments. You also know that he is going to learn something. Students in their second year still have to develop. They cannot take on big assignments right away. Such students should be supervised differently. I think we should try to pursue that.

In this team, the different perspectives remain visible in subsequent interviews and focus group. On the other hand, in other teams such as Eco-SVE and the Tech-SVE, members started to take and use each other's perspectives. A comparison between the first talks recorded during meetings and the focus group discussions shows that the members also trust each other in doing so. The following excerpt from the focus group discussions with the Edu-SVE ET shows that one's own perspective can also be questioned.

(W1 and W2: workplace supervisors primary school, P1 and P2: program supervisors for educational assistants)

W1: There is not just one person that coordinates the internships in our institution.

W2: It is more an empty function.

P1: So it should be more dressed up, sitting on more body. Because we also have someone within the program that placements, or that controls the contact but that is really just a pass-through function.

W1: Yes only administrative.

P1: Has nothing to do with content.

P2: For us, this has also consequences. At present, our policy is that all students have their own supervisors, but that means there are as many as five people passing by one school. It's a big change to do so in an ET manner. On the other hand, I do believe that what you say is very valuable and that we need revisit our thinking on this. 


\section{Team Development: Shared repertoire}

The initial discussions during the meetings indicate that the shared repertoire is in a preliminary stage of development and that the teams rely heavily on the structure that is provided by the project management. During the year, all ETs left the regulation of interaction to the project organization, and only discussed these matters when prompted.

The way the ETs build upon each other during the discussions (intellectual building) throughout the course of the year varies per team. The ETs from Edu-HVE, Edu-SVE and TechSVE began doing so from meeting two (see excerpt). With the other teams, we see that in the beginning, the program leaders especially build on the contributions of the workplace supervisors. From the focus group onward, this building becomes more evenly balanced. The following excerpt from a conversation the Edu-SVE ET shows that, in this team, critical points are taken aboard rather than parried.

(W1, W2, W3: workplace supervisors in primary schools, P1, P2: program supervisors for educational assistants)

W2: Students join you in the contact groups, right?

P1: Yes.

W2: It seems to me that it is very important for the program to know what happens there. What do you do? This would help us to dialogue with the students.

$[\ldots]$

P2: We come two or three times to visit.

P1: Should that be more often?

W1: I think four times would be suitable.

A: And not only when assessing.

W1: But also just to have a look sometime. You come for meetings, but you can also come during a lesson.

W3: I think that's very good idea.

W1: For example, I'm thinking about a video interaction [explains].

P2: Yes, I think therefore that two students should come.

P1: I find this very interesting. Can you explain something a bit more clearly.

The following excerpt from an interview of the Eco-SVE ET shows that they bring each other's ideas into the discussion.

(P: program supervisor; W: workplace supervisor)

P: But what we see now is that both students see no connection between what they learn in school and what they do when they are with you.

W: No, that might be possible, but I'm working with them. I know that these students do not know everything. They know very little about VAT. And if you want to link theory with practice, you will also have to arrange it carefully.

P: Yes, that's an issue for us which is led us by the qualification policies. These should be changed. We supplement of course, but that might not be enough.

[...]

W: So, it's about coordination?

P: Yes, I now know that some theoretical knowledge is not present.

$\mathrm{W}$ : Yeah, I know that there is a major shortage in this area. 
[...]

W: Creating training materials, we can do that. I've actually already written things down concretely.

P: I suggest that. I also make teaching aids. This is something I'd like to remember. Look, I hear things, and now I'm hearing new things. I would really like to have this arranged.

$\mathrm{W}$ : Yes, because it is usually too late and now we can have it ready.

Comparison of interviews shows that the program supervisor takes ideas from the workplace supervisor. This phenomenon is also reflected in the ET Tech-HVE. The role distribution is often determined in a natural way. In most cases this distribution sustained. Only the Edu-HVE ET explicitly discussed and altered roles. In the other teams, roles were discussed only when they were asked about them. In many cases, the roles team members play can be linked to their professional roles. Thus, in teams in which the implementation of the intervention primarily takes place at the school, the duties of the program supervisor tend to be also larger and vice versa. It is striking that, in most cases, the team members of schooling programs ultimately have the most tasks. Exceptions to this are the ETs Edu-HVE, where workplace supervisors are responsible for setting and supervising the intervention, and Eco-HVE, where members reported a similar distribution.

When asked whether the ET is a real team, the majority of the interviewees said that this is not yet the case. For instance, this is reflected in the individual interviews with members of the ET Edu-HVE.

(W1 and W2: workplace supervisors, P1 and P2: program supervisors for teacher education)

W1: No, absolutely not. It still has had no change in leadership. It would help if we could work with someone who has overarching book knowledge for a whole day.

P1: No, we have not yet been at this long enough.

$\mathrm{P} 2$ : We have not functioned as a team yet.

W2: I think not just yet, but I also think it can become a good team.

The video recordings of the meetings show that the team members still very much leave the structure of activities in the hands of the project leaders. They are content, unanimously it seems, to come together at the agreed-upon times and continue then. In fact, participants mentioned that they were happy for the trainer/researchers to take the initiative. The analyses of the interviews show that the team members have no explicit or implicit roles during collaborative work.

\section{Team development: Joint enterprise}

The video recordings of both the first and the second trainings show that, within the ETs, fairly quick consensus is reached on the general subjects they will work on for their projects. However, with the exception of the Edu-HVE ET, the specific goals to be addressed within those subjects, are not sharply defined right away. Among other observations, that can be inferred from the conversations that took place during the first and second meetings. During these meetings, the intention was that consensus would emerge with regard to the goals. In these teams, the goals were discussed in almost the same way as during the first and the second meetings.

The individual interviews show that further in time there is still consensus on the topic being worked on. What is striking, is that even now the goals are re-discussed. During the focus 
group discussion of Edu-HVE ET, it is notable that conversations concerning the goals show more detail. At the other end of the spectrum, the Eco-SVE ET, discusses the object over and over again in a manner that is similar to the discussions that took place during the first two meetings (see also above fragment). Such processes are also reflected in the Eco-HVE team. Except for the Tech-SVE team, where the goals are not discussed, we see "regression" into the discussion of the objective to be achieved in almost all ETs. The following fragment from the ET Tech-HVE shows that the debate about the function of the internships partially repeats itself. However, in comparison with the forming phase, the content of the discussion is of a higher quality.

(P1 and P2: program supervisor; W: workplace supervisor; $R$ : researcher)

$\mathrm{R}$ : OK, I'll make another round. Can I start with you? What do you think should be the aim in your intervention?

W: How do we ensure a good match between the students and the company in which they will be placed.

P1: Better match between the aims of the student and the workplace. Workplace more in line with the expectations.

P2: Good match between student and internship site.

W: Period [no additions].

P2: P1 says learning aims of the student.

$\mathrm{R}:$ There are minor differences?

P2: Yes, I experience differences.

$\mathrm{R}$ : That is something we should talk about. P1 could you explain again?

P1: Yes, students should be able to get more out of the internship by knowing ahead of time what they want to learn and that this is also possible in the context of the workplace.

P2: I think P1 means that a match is good if a student can reach his learning goal.

$\mathrm{W}$ : The match was obvious.

P2: I think we should just talk about the match between the places.

$\mathrm{W}$ : Yes.

The results of the questionnaire and discussion of these results with members of the ETs and the first conversations demonstrate that education terms, such as workplace learning, competence, qualification framework and portfolio have been interpreted differently by the members of the ETs Edu-SVE, Tech-HVE, Tech-SVE, Eco-HVE and Eco-SVE at the beginning of the year. The members of the ET Edu-HVE already use the same definitions for the most part. Later in the year we see a change in this regard. For example, when ET Edu-SVE adopt the term, qualification framework. More often, however, the common knowledge is much more extended by sharing images of "the other context". The following fragment during the focus group discussion with the Eco-SVE ET shows how these perspectives of the other context are also discussed at a later stage.

(W: workplace supervisor; P: program supervisor)

$\mathrm{W}$ : I've written down better coordination between what practice asks and what is taught at school. Besides this making new trainees aware of what is happening during an internships.

$\mathrm{P}$ : There is something in common in but I look at it more from the school situation. Motivating students for the profession and showing them that knowledge 
from school is actually required in professional practice. The usefulness of such knowledge, with which I am engaged at school.

$[\ldots]$

W: But that's not what I mean.

P: No exactly, that's not what you mean.

W: Indeed, it has to do with the fact that we look at the problem from different perspectives. To be more precise I find that what the students can actually do, is really not sufficient to function in practice.

P: Oh yes, but it also may have to do with the fact that, even though we try to do all kinds of things, it is still not clear to the student.

$\mathrm{W}$ : Yes, but there are also certain basic skills that are simply not taught.

P: Basic knowledge or basic skills.

Finally, the results of the questionnaire and discussion of its results with the ETs during the meetings at the beginning of the year demonstrate that the team members based their information about workplace learning mainly on knowledge they have gained during the training and courses and personal experiences. Members of the Edu-HVE and Edu-SVE also indicate that they consulted literature. Members of the ETs Tech-HVE and Eco-SVE mention colleagues and the handbook for workplace supervisors as important resources. From both individual interviews and focus group discussions later in the year, it becomes clear that a need seems to arise for more (common) knowledge on the subject of workplace learning. An exception is the ET TechHVE. None of the three members of this ET indicate needs for additional information, literature, courses or otherwise at this stage. In the other ETs, the majority has consistently indicated that they did need such resources. In addition, during the focus group discussions, the ETs Edu-HVE, Edu-SVE and Eco-SVE expressed a desire to share the experiences from the project with colleagues. Reasons for doing so were, among others, that colleagues can have a valuable input, but also can answer the question of whether the ETs are doing the right things.

In summary, we see that both positive and negative indications of change in the three dimensions have been found in all teams. We see that, in all cases, a nuanced picture becomes visible with regard to the indicators mentioned in the theoretical framework. However, if we only focus on those indicators that change significantly during the year, we see an image as shown in Table 2.

[Insert Table 2 about here]

\section{Professional growth of individual team members}

An overview of the professional growth of team members, based on a comparison of the questionnaires shows that, obviously, the growth per person is different. In this section, we therefore try to focus on the most important changes. Answers to questions that related to personal image of workplace learning and school learning show that almost all members have become more specific in their descriptions of goals and components. For some team members, we see that this specification is traceable to characteristics of their own projects. For example, a workplace supervisor from the Edu-SVE ET, whose intervention focuses on communication between the two contexts, gave the following answer to the question about what key components of workplace learning are: 
Workplace supervisor Edu-SVE:

First questionnaire: "Good textbooks and a good explanation and discussion on the school."

Second questionnaire: "Good communication between education and the workplace."

In the beginning of the year, team members stressed that especially colleagues, books and training courses have been important as sources of information. At the end of the year, that image is similar but by various team members it is supplemented with the 'experiences from the Extended Team' or 'supervisors of the different contexts'. Team members indicate that they have more understanding of the different contexts (school and workplace) and that they have become aware of the complexity of certain (border) problems that go with workplace learning and the connection with school learning. For example, a program supervisor from the Edu-HVE ET gave the following answers to the question: "What sources of information (. Eg websites, courses, books, colleagues) about workplace learning are important to you (were)?"

\section{Program Supervisor Edu-HVE:}

First questionnaire: "The information provided by the training, teaching to fourth students, experience in education."

Second questionnaire: "School Educators from the Extended Team, coaches, peers, teaching to fourth year students, personal experiences."

When asked how such resources have influenced his knowledge and thinking about workplace learning, he answered: "Experience: knowledge of the environment, school teachers and coaches: knowledge of current developments in the context of the school and colleagues, knowledge of pedagogy."

During the year, team members are equally satisfied or slightly more satisfied with the way in which learning and supervising is shaped in their own workplace. In several cases, the increase in satisfaction has to do with an increase in the awareness at their own workplace that the relationship between workplace learning and school learning is important. One workplace supervisor said that developing the ET's own intervention is the main reason for satisfaction.

As for the results that can be achieved with students, the questionnaires show that almost all team members are still as positive at the end of the year are as they were at the beginning. The reason for the satisfaction related to the students is that, according to some team members, they expect the intervention will really contribute or has already helped. Finally, the team members have clearly become more enthusiastic about what can be achieved with the project. Here too, several respondents mention that the performance of students will benefit as a result.

\section{Conclusion and discussion}

Six ETs started work with the aim of improving alignment between learning in the workplace and in the school context. The ETs worked together to find solutions for (parts of) this 'alignment problem' and in the early stages of this process, they were accompanied by a team of educational specialists. This paper offers insights into both the functioning of ETs and the personal professional growth of individuals within ETs. The new understanding should ultimately result in guidelines for optimal support of ETs.

We evaluated the first year of ET work. During that period ETs went through the forming and storming phases of Tuckman's (1965) team development model. Positive changes related to mutual engagement and shared repertoire among ET members indicate 'growth' in the forming 
phase of the ET projects. Changes, both positive and negative, regarding shared repertoire and joint enterprise show the stormy character of ET projects later that year (see Table 2)

On the question concerning which dimensions of team work at the ETs change is observed, it may be concluded that with the exception of one, the ETs have shown marked changes in all dimensions of CoP development (Brouwer et al., 2012; Wenger, 1998) during their first year of working at the border of school and workplace setting. In addition, trends are detected in these changes that emerge in most teams. Specifically, we see an increase in the social ties in most teams. Changes in intellectual building, i.e. the extent to which team members build on each other, appears to be present within all but one team. Further, we see that in all teams, the participation of team members in the discussions and the tasks and the flexibility in that (dynamic effort) does not amount to an equal distribution and that the distribution that is manifest is often traced back to the context in which the team activities are directed (school or workplace). Finally, it appears that almost all the teams have developed a need for more knowledge about workplace learning and its relationships with school learning.

Regarding the domains in which professional growth can be observed individual team members, it can be concluded that:

- Ideas about goals and components of workplace learning and knowledge and attitudes about the other context in the "personal domain" have changed discernible for most team members by working in the ET (Domain of practice);

- Team member ideas concerning what can be achieved by and for students (Salient outcomes) were discernibly changed by participating in the project.

The results of this study show changes in ET performance on some indicators. However, we also see that the changes for the different teams vary. In what ways might team composition have influenced the overall functioning of each team? Here, we reflect on our findings in light of team diversity and team size. Thereafter, we discuss implications of the findings related to professional growth of participants, and team functioning for advancing the concept and practice of ETs.

An important point of departure in establishing the ETs was that the composition of the ETs should reflect the normal working relationships between teachers and workplace supervisors and other kinds of diversity in the domain. Based on the data from this study, we infer that diversity in professional background was central to both ET development and personal professional growth. For instance, in the first year of ET-development, the topics of the team talks often related to differences between workplace and school, as evidenced by differences in objectives of work placement or in the perspectives on workplace learning. Indeed, the presence of role and task-based diversity appears to have provided the primary mechanism for developing new insights (individual professional growth) and working as a CoP (team development). Here, the diversity seems to have facilitated "brokering - connections provided by people who can introduce elements of one practice into another," (Wenger, 1998, p. 105). Although not an explicit focus of this study, we did reflect on the data in light of demographic diversity. As we were not able to identify any affordances or limitations related to ethnicity or gender, the findings of this study are consistent with existing research, which shows that task diversity, not biographical diversity, influence team performance (Horwitz \& Horwitz, 2007; Joshi \& Roh, 2009). Additional research is needed to establish if this is the case in other settings, with other ETs, and with other kinds of CoPs.

In contrast to Nieuwenhuis et al. (2011), we started this study with relatively small groups. In the context of these ETs, note two factors that seem worth considering in regard to team size. First, for teams to be sustainable, the number of members must be limited to that which 
the institutions can facilitate. Even in this grant-supported project, freeing up time to attend meetings and work collaboratively proved challenging. Second, as teams grow in size, efficiency and inter-dependencies are more at risk. Small teams can benefit from fewer and shorter lines of communication, and the participation (or not) of each member is highly visible to others. For instance, in the focus group members of the Edu-HVE ET pointed out that despite their busy time schedules they were able to get together and work efficiently because of the relative small group size. Thus, with the exception of a single two-person team (which we view as fragile), the findings from this study are consisted with existing literature on the performance of small working groups (Tuckman, 1965; Wheelan, 2009), which indicate that groups of less than 10, and preferably between three and six members, perform best. However, to confirm the benefits of small ETs over large ones, comparative research would be necessary.

As for individual professional growth of its members, we see that working together in an ET appears to influence the ideas and knowledge of members about workplace learning and the ideas and knowledge about what that might mean for students. For teachers in both vocational and general education, such insights may be quite significant. One of the main objectives of education is that it prepares for society, including working life. The knowledge, attitudes and skills of teachers, who act as role models for their students, probably have a strong impact on the quality of that preparation and the pedagogical skills (Roefs, 2010; Van Kan, Zitter, Brouwer, \& Van Wijk, 2014). With this in mind, teachers in vocational education should have a sound insight in the vocations for which students are prepared. Working in an ET appears to contribute to that part of their professionalism.

Because after one year, the teams mostly were not so far that they could test their interventions fully in practice, there has not yet much clarity about the influence of observable effects in students and how those effects influence the thinking and work of team members. The lack of knowledge about this relationship for professional growth also requires further research. In the coming years of the project, attention will be given to this issue. Another question that future research on professional growth could focus on pertains to influences from different areas and the impacts on professional growth of team members that were measured - do they apply more broadly, or are they specific for ETs?

The above questions concerning the generalizability of our findings give rise to further discuss the ET-specific team function and ET-specific growth. By this we mean the changes that are characteristic of the collaboration and learning on the border of the school and workplace settings. Literature about working and learning in and across borders (e.g., Tuomi-Gröhn \& Engeström, 2003; Vähäsantanen, Saarinen, \& Eteläpelto, 2009) shows that changes in indicators of team performance can be expected and that the joint work on education leads to frictions between, for example, goals, ways of thinking, and methods from the various contexts (see also Akkerman \& Bakker, 2011). A look at the results and experiences of this year with this perspective shows that the following indicators (Brouwer et al., 2012) for team functioning may show a change that is characteristic of ETs.

With regard to the dimension Mutual engagement those indicators are (a) Multiperspective contribution, because different ideas may be embedded in the group in the training context and / or the workplace context and (b) Mutual trust and responsibility, because responsibility for the team may conflict with responsibilities for work in their own context. Regarding the dimension Shared repertoire that the indicators are (a) Intellectual building because the input of members from different contexts can be based on widely varying experiences and knowledge, (b) Role-taking because roles and positions in the ET may be determined by the context in which they operate outside the team and (c) Dynamic effort because 
the context can determine the ability to perform tasks within the group. Finally, as regards the dimension Joint enterprise, indicators are (a) Commitment to domain because the goals being worked on in the ET by members of the different contexts can be interpreted very differently or worked out and (b) common ground in concept because different interpretations of concepts can characterize participants from different contexts.

The aforementioned literature about working and learning at and over the boundaries of school and workplace could possibly provide insight into whether the perceived professional growth of ET-members is generally applicable or specific to ETs. Through the frictions that result from confrontations with the other context, in which other perspectives and different philosophies and methods are used, four boundary specific learning mechanisms occur, according to Bakker and Akkerman (2014). These confrontations encourage / enforce members of ETs to reconsider one's own thinking and working methods. In such cases, both the picture of the different context and the image of the own context can change, prompting reconsideration of thinking and practice occurs. Reasoning from this perspective, it is possible that the four learning mechanisms mentioned by Bakker and Akkerman are observable when collaborating in ETs, and form a bridge between the confrontations in an ET and the professional development of individual members. The four learning mechanisms (Bakker and Akkerman, 2014) can be expressed as follows by ETs. Identification occurs when ET-members understand how training and workplace itself differ. Coordination is revealed as ET-members use procedures and objects that facilitate effective cooperation between school and the workplace. Reflection is visible when ET members become aware of the differences in perspectives between the other and the own context. Finally, Transformation takes place as ET-Members make connections between school and workplace to realize new connections or even function collectively as a new context.

In interpreting the findings of the study, several limitations bear mention. First, although construct validity of the questionnaire was assessed by the research team $(n=3)$ until $100 \%$ consensus was reached, validation by additional experts without connections to the study could have increased the construct validity. Second, to increase response rates (especially to the open questions), the number of items on the questionnaire was intentionally kept to a minimum. Given the resulting low numbers of closed items, it was not deemed useful to test for internal consistency. Third, in an effort to minimize obtrusiveness, member checks were not conducted with the interview data.

Despite the aforementioned limitations, we conclude that relations between the dimensions of team functioning and the domains of individual professional growth and learning mechanisms of boundary crossing are worth exploring. This is because they may provide explanations for the observed or even perceived changes in the performance of ETs as a whole as well as the individual growth of ET-members. This study was designed to gain insight into ETs, a form of cooperation in which workplace supervisors and program teachers work together to improve connections between school learning and internships. The results show that ET-members actually learn about functioning in their own context, in part by understanding more about the other context. In the short period of one year, positive effects of such boundary crossing already became visible in terms of the personal development of team members and the functioning of the teams as a whole. Further research on longer term ET collaboration is required to understand long term effects on individuals, effects related to additional indicators, and the effects on students. Investigation into these factors would not only discern if the students benefit from the ET interventions, but also explain relationships between team composition and the final results. 


\section{References}

Admiraal, W., \& Lockhorst, D. (2010, May). A descriptive model of teacher communities. Paper presented at the annual meeting of the American Educational Research Association, Denver, CO.

Akkerman, S. F., \& Bakker, A. (2011). Boundary crossing and boundary objects. Review of Educational Research, 81, 132-169. doi:10.3102/0034654311404435

Aviv, R. (2001). Educational performance of ALN via content analysis. Journal of Asynchronous Learning Networks, 4(2), 53-72. doi:10.1.1.131.7147

Bakker, A., \& Akkerman, S. F. (2014). Leren door boundary crossing tussen school en werk [Learning by boundary crossing between school and work]. Pedagogische Studiën, 91, 823.

Brouwer, P., Brekelmans, M., Nieuwenhuis, L., \& Simons, R. (2012). Community development in the school workplace. International Journal of Educational Management. 26, 403-418. doi:10.1108/09513541211227809

Clarke, D., \& Hollingsworth, H. (2002). Elaborating a model of teacher professional growth. Teaching and Teacher Education, 18, 947-967. doi:10.1016/S0742-051X(02)00053-7

Heilman, E. E. (2001). Teachers' perspectives on real world challenges for social studies education. Theory \& Research in Social Education, 29, 696-733. doi:10.1080/00933104.2001.10505962

Horwitz, S. K., \& Horwitz, I. B. (2007). The effects of team diversity on team outcomes: A metaanalytic review of team demography. Journal of Management, 33, 987-1015. doi:10.1177/0149206307308587

Joshi, A., \& Roh, H. (2009). The role of context in work team diversity research: A meta-analytic review. Academy of Management Journal, 52, 599-627. doi:10.5465/AMJ.2009.41331491

Kirschner, P., \& Wopereis, I. G. J. H. (2003). Mindtools for teacher communities: A European perspective. Technology, Pedagogy and Education, 12, 105-124. doi:10.1080/14759390300200148

Lieberman, A., \& Pointer Mace, D. (2010). Making practice public: Teacher learning in the 21st Century. Journal of Teacher Education, 61, 77-88. doi:10.1177/0022487109347319

McLaughlin, M. \& Talbert, J. (2006). Building school-based teacher learning communities. Professional strategies to improve student achievement. London: Teachers College.

Miles, M. B., \& Huberman, A. M. (1994). Qualitative data analyses: An expanded sourcebook (2nd ed.). Thousand Oaks, CA: Sage.

Nieuwenhuis, A. F. M., Nijman, D. J. J. M., Kat-De Jong, M. P., De Ries, K. E., \& Van Vijfeijken, M. M. (2011). De doorbraak in zicht: Landelijke tussenrapportage Doorbraakproject werkplekleren 2009-2011 [The breakthrough in sight: National interim report Breakthrough Project Workplace Learning 2009-2011]. Tilburg, the Netherlands: IVA beleidsonderzoek en advies.

Roefs, E. (2010). Inspirerende docenten: Inzichten en verhalen uit het hoger beroepsonderwijs [Inspiring teachers: Opinions and stories from higher education]. Antwerpen/Apeldoorn, the Netherlands: Garant.

Schaap, H., Baartman, L., \& De Bruijn, E. (2012). Students' learning processes during schoolbased learning and workplace learning in vocational education: A review. Vocations and Learning, 5, 99-117. doi:10.1007/s12186-011-9069-2

Truijen, K. J. P., Sleegers, P. J. C., Meelissen, M. R. M., \& Nieuwenhuis, A. F. M. (2013). What makes teacher teams in a vocational education context effective?: A qualitative study of 
managers' view on team working. Journal of Workplace Learning, 25, 58-73.

doi:10.1108/13665621311288485

Tuckman, B. (1965). Developmental sequence in small groups. Psychological Bulletin, 63, 384399. doi: $10.1037 / \mathrm{h} 0022100$

Tuomi-Gröhn, T., \& Engeström, Y. (Eds.) (2003). Between school and work: New perspectives on transfer and boundary crossing. Oxford: Pergamon.

Tynjälä, P. (2008). Perspectives into learning at the workplace. Educational Research Review, 3, 130-154. doi:10.1016/j.edurev.2007.12.001

Vähäsantanen, K., Saarinen, J., \& Eteläpelto, A. (2009). Between school and working life: Vocational teachers' agency in boundary-crossing settings. International journal of educational research, 48, 395-404. doi:10.1016/j.ijer.2010.04.003

Van Kan, C., Zitter, I., Brouwer, P., \& Van Wijk, B. (2014). Onderwijspedagogische visies van mbo-docenten: Wat dient het belang van studenten? [Pedagogical views of teachers in secondary vocational education :What serves the interest of students?]. 's-Hertogenbosch, the Netherlands: Expertisecentrum Beroepsonderwijs.

Wheelan, S. A. (2009). Group size, group development, and group productivity. Small Group Research, 40, 247-262. doi:10.1177/1046496408328703

Wenger, E. (1998). Communities of practice: Learning, meaning, and identity. Cambridge, UK: Cambridge University Press.

Yin, R. (2003). Case study research: Design and methods (3rd. ed.). Beverly Hills, CA: Sage. 
Figure 1. Interconnected Model of Professional Growth (Clarke \& Hollingsworth, 2002) 
Table 1

Characteristics of Six Extended Teams

\begin{tabular}{|c|c|c|c|c|c|c|}
\hline \multirow{3}{*}{ Sub domain } & \multicolumn{6}{|c|}{ Extended Teams } \\
\hline & \multicolumn{2}{|c|}{ Educational domain (Edu) } & \multicolumn{2}{|c|}{ Technical domain (Tech) } & \multicolumn{2}{|c|}{ Economical domain (Eco) } \\
\hline & $\begin{array}{l}\text { Teacher } \\
\text { training }\end{array}$ & $\begin{array}{l}\text { Teacher } \\
\text { assistance }\end{array}$ & Polytechnics & $\begin{array}{l}\text { Mechanical } \\
\text { engineering }\end{array}$ & $\begin{array}{l}\text { Bussiness } \\
\text { administration }\end{array}$ & $\begin{array}{l}\text { Bussiness } \\
\text { administration }\end{array}$ \\
\hline Level & HVE & SVE & HVE & SVE & HVE & SVE \\
\hline Team size & 4 & 5 & 3 & 3 & 3 & 2 \\
\hline Male/Female & $2 / 2$ & $0 / 5$ & $3 / 0$ & $3 / 0$ & $3 / 0$ & $1 / 1$ \\
\hline $\begin{array}{l}\text { Team input } \\
\text { schools }\end{array}$ & $\begin{array}{l}\text { Teacher } \\
\text { trainers } \\
(\mathrm{n}=2)\end{array}$ & $\begin{array}{l}\text { Teachers } \\
\operatorname{SVE}(n=2)\end{array}$ & $\begin{array}{l}\text { Teachers } \\
\operatorname{HVE}(n=2)\end{array}$ & $\begin{array}{l}\text { Teachers } \\
\text { SVE }(n=2)\end{array}$ & $\begin{array}{l}\text { Teacher HVE } \\
(\mathrm{n}=1)\end{array}$ & $\begin{array}{l}\text { Teacher SVE } \\
(\mathrm{n}=1)\end{array}$ \\
\hline $\begin{array}{l}\text { Team input } \\
\text { workplace }\end{array}$ & $\begin{array}{l}\text { Secondary } \\
\text { school } \\
\text { teachers } \\
(\mathrm{n}=2)\end{array}$ & $\begin{array}{l}\text { Elementary } \\
\text { school } \\
\text { teachers } \\
(\mathrm{n}=3)\end{array}$ & $\begin{array}{l}\text { Consumer } \\
\text { lifestyle } \\
\text { electronics } \\
(n=1)\end{array}$ & $\begin{array}{l}\text { Mechanical } \\
\text { engineer } \\
(\mathrm{n}=1)\end{array}$ & $\begin{array}{l}\text { Business } \\
\text { administrators } \\
(\mathrm{n}=2)\end{array}$ & $\begin{array}{l}\text { Accountant } \\
(\mathrm{n}=1)\end{array}$ \\
\hline Abbreviation & Edu-HVE & Edu-SVE & Tech-HVE & Tech-SVE & Eco-HVE & Eco-SVE \\
\hline
\end{tabular}

Note: HVE is Higher Vocational Education; SVE is Senior Vocational Education 
Table 2. Observable changes in Extended Teams for dimensions and indicators of team performance

\begin{tabular}{|c|c|c|c|c|c|c|c|c|c|c|c|c|}
\hline \multirow{2}{*}{$\begin{array}{l}\text { Dimension } \\
\text { of team } \\
\text { functioning }\end{array}$} & \multicolumn{12}{|c|}{ Extended Team } \\
\hline & \multicolumn{2}{|c|}{$\begin{array}{l}\text { Edu-HVE } \\
(\mathrm{N}=77)\end{array}$} & \multicolumn{2}{|c|}{$\begin{array}{l}\text { Edu-SVE } \\
(\mathbf{N}=83)\end{array}$} & \multicolumn{2}{|c|}{$\begin{array}{l}\text { Tech-HVE } \\
(\mathrm{N}=67)\end{array}$} & \multicolumn{2}{|c|}{$\begin{array}{l}\text { Tech-SVE } \\
(\mathrm{N}=58)\end{array}$} & \multicolumn{2}{|c|}{$\begin{array}{l}\text { Eco-HVE } \\
(\mathrm{N}=68)\end{array}$} & \multicolumn{2}{|c|}{$\begin{array}{l}\text { Eco-SVE } \\
(\mathrm{N}=73)\end{array}$} \\
\hline $\begin{array}{l}\text { Mutual } \\
\text { engagement }\end{array}$ & + & $\begin{array}{l}\text { Social ties } \\
(\mathrm{n}=8)\end{array}$ & + & $\begin{array}{l}\text { Identification } \\
(n=7) ; \text { Multi- } \\
\text { perspective } \\
(n=11) \text {; Social } \\
\text { ties }(n=4)\end{array}$ & + & & + & $\begin{array}{l}\text { Multi - } \\
\text { perspective } \\
(\mathrm{n}=5) ; \\
\text { Social ties } \\
(\mathrm{n}=3)\end{array}$ & + & $\begin{array}{l}\text { Mutual } \\
\text { trust }(\mathrm{n}=2)\end{array}$ & + & $\begin{array}{l}\text { Multi- } \\
\text { perspective } \\
(\mathrm{n}=11) ; \\
\text { Mutual trust } \\
(\mathrm{n}=4) ; \\
\text { Social ties } \\
(\mathrm{n}=4)\end{array}$ \\
\hline & - & & - & & - & & - & & - & & - & \\
\hline \multirow[t]{2}{*}{$\begin{array}{l}\text { Shared } \\
\text { repertoire }\end{array}$} & + & $\begin{array}{l}\text { Intellectual } \\
\text { building } \\
(\mathrm{n}=13) ; \\
\text { Regulation } \\
\text { interaction } \\
(\mathrm{n}=5)\end{array}$ & + & $\begin{array}{l}\text { Intellectual } \\
\text { building }(n=9)\end{array}$ & + & & + & $\begin{array}{l}\text { Intellectual } \\
\text { building } \\
(\mathrm{n}=6)\end{array}$ & + & $\begin{array}{l}\text { Dynamic } \\
\text { effort } \\
(n=3)\end{array}$ & + & \\
\hline & - & $\begin{array}{l}\text { Dynamic } \\
\text { effort }(n=5)\end{array}$ & - & $\begin{array}{l}\text { Dynamic } \\
\text { effort }(n=9)\end{array}$ & - & $\begin{array}{l}\text { Intellectual } \\
\text { building } \\
(\mathrm{n}=15) ; \\
\text { Dynamic } \\
\text { effort } \\
(\mathrm{n}=5)\end{array}$ & - & $\begin{array}{l}\text { Dynamic } \\
\text { effort }(n=3)\end{array}$ & - & & - & $\begin{array}{l}\text { Intellectual } \\
\text { building } \\
(n=12) ; \\
\text { Dynamic } \\
\text { effort }(n=5)\end{array}$ \\
\hline \multirow[t]{2}{*}{$\begin{array}{l}\text { Joint } \\
\text { enterprise }\end{array}$} & + & $\begin{array}{l}\text { Shared } \\
\text { knowledge } \\
(\mathrm{n}=11)\end{array}$ & + & $\begin{array}{l}\text { Common } \\
\text { concept } \\
(\mathrm{n}=8) ; \text { Shared } \\
\text { knowledge } \\
(\mathrm{n}=7)\end{array}$ & + & & + & $\begin{array}{l}\text { Shared } \\
\text { knowledge } \\
(\mathrm{n}=6)\end{array}$ & + & $\begin{array}{l}\text { Shared } \\
\text { knowledge } \\
(n=4)\end{array}$ & + & $\begin{array}{l}\text { Shared } \\
\text { knowledge } \\
(\mathrm{n}=10)\end{array}$ \\
\hline & - & & - & & - & & - & & - & & - & $\begin{array}{l}\text { Common } \\
\text { concept } \\
(\mathrm{n}=7)\end{array}$ \\
\hline
\end{tabular}

Note: ' + ' = indicators (eg, Social Features) in which predominantly positive detectable changes have been found; '-' = Indicators in which predominantly negative detectable changes have been found; an empty field means that it was no clear positive or negative effect on the detectable change for these indicators. $\mathrm{N}$ $=$ total number of relevant meaning units; $\mathrm{n}=$ number of relevant meaning units related to the specific indicator 